\title{
Atlantis
}

Critical Studies in Gender, Culture \& Social Justice

Études critiques sur le genre, la culture, et la justice

\section{Modernity and Progress: The Transnational Politics of Suffrage in British Columbia (1910-1916)}

\section{Lara Campbell}

Volume 41, Number 1, 2020

URI: https://id.erudit.org/iderudit/1074021ar

DOI: https://doi.org/10.7202/1074021ar

See table of contents

Publisher(s)

Mount Saint Vincent University

ISSN

1715-0698 (digital)

Explore this journal

Cite this article

Campbell, L. (2020). Modernity and Progress: The Transnational Politics of Suffrage in British Columbia (1910-1916). Atlantis, 41(1), 90-104.

https://doi.org/10.7202/1074021ar

\section{Article abstract}

Canadian historians have underplayed the extent to which theproject of suffrage and first wave feminism was transnational in scope. The suffrage movement in British Columbia provides a good example of the global interconnections of the movement. While BC suffragists were relatively uninterested in pan-Canadian campaigns they explicitly situated provincial suffrage within three transnational relationships: the 'frontier' myth of the Western United States, radical direct action by suffragettes in the United Kingdom, and the rise of modern China. By the second decade of the 20thcentury, increasingly confident women's suffrage societies hosted international visits and contributed to global print culture, both of which consolidated a sense of being part of a modern, international and unstoppable movement.

BC suffragists were attuned to American suffrage campaigns in California, Oregon and Washington, which granted female suffrage after referenda and situated political rights for settler women in the context of Western progress narratives. The emphasis on progress and modernity intersected with growing connections to non-Western countries, complicating racialized arguments for settler women's rights to vote. BC suffragists were particularly impressed by the role of feminism in Chinese political reform and came to understand Chinese women as symbolizing modernity, progress, and equality. Finally, the militant direct action in the British suffrage movement played a critical role in how BC suffragists imagined the role of tactical political violence. They were in close contact with the militant WSPU, hosted debates on the meaning of direct action, and argued that suffragettes were heroes fighting for a just cause. They pragmatically used media fascination with suffragette violence for political purposes by reserving the possibility that unmet demands for political equality might lead to Canadian conflict in the future.
All Rights Reserved (C Lara Campbell, 2020

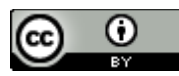

This document is protected by copyright law. Use of the services of Érudit (including reproduction) is subject to its terms and conditions, which can be viewed online. 


\section{Modernity and Progress: The Transnational Politics of Suffrage in British Columbia (1910-1916)}

Lara Campbell is a Professor in the Department of Gender, Sexuality, and Women's Studies at Simon Fraser University in Vancouver, British Columbia. She is the author of Respectable Citizens: Gender, Family, and Unemployment in Ontario's Great Depression (UTP, 2009) and A Great Revolutionary Wave: Women and the Vote in British Columbia (UBC Press, 2020). Her current research is on the history of Vietnam War and the transnational and gendered politics of the draft resistance and antiwar movements in North America.

Abstract: Canadian historians have underplayed the extent to which the project of suffrage and first-wave feminism was transnational in scope. The suffrage movement in British Columbia provides a good example of the global interconnections of the movement. While BC suffragists were relatively uninterested in pan-Canadian campaigns they explicitly situated provincial suffrage within three transnational relationships: the 'frontier' myth of the Western United States, radical direct action by suffragettes in the United Kingdom, and the rise of modern China. By the second decade of the 20th century, increasingly confident women's suffrage societies hosted international visits and contributed to global print culture, both of which consolidated a sense of being part of a modern, international, and unstoppable movement. BC suffragists were attuned to American suffrage campaigns in California, Oregon, and Washington, which granted female suffrage after referenda and situated political rights for settler women in the context of Western progress narratives. The emphasis on progress and modernity intersected with growing connections to non-Western countries, complicating racialized arguments for settler women's rights to vote. $\mathrm{BC}$ suffragists were particularly impressed by the role of feminism in Chinese political reform and came to understand Chinese women as symbolizing modernity, progress, and equality. Finally, the militant direct action in the British suffrage movement played a crit- ical role in how BC suffragists imagined the role of tactical political violence. They were in close contact with the militant WSPU, hosted debates on the meaning of direct action, and argued that suffragettes were heroes fighting for a just cause. They pragmatically used media fascination with suffragette violence for political purposes by reserving the possibility that unmet demands for political equality might lead to Canadian conflict in the future.

Keywords: first-wave feminism, suffrage 
$\mathrm{D}$ uring the first two decades of the twentieth century, suffrage victory in British Columbia seemed to be within sight as New Zealand, Australia, Norway, and several neighbouring American states granted female enfranchisement. Feminist historians have documented the promise and limitations of modern global suffrage organizing and traced the complicated connections of imperialism and colonialism with national suffrage movements (Baillargeon 2019; Brookfield 2018; Forestell and Moynagh 2018; Sangster 2018). Historian Nancy Forestell argues that as much as local suffragists were immersed in local and provincial contexts, it is important to understand how the movement was situated within a transnational framework (2005). Since most suffragists in British Columbia could not afford international travel, they learned about the global movement at lectures given by touring suffragists or by reading mainstream or specialist print culture.

Suffragists in British Columbia had advocated for the vote in reform, women's, and political organizations beginning in the 1880s (Gough 1988; Kealey 1998; Newton 1995; Strong-Boag 2015; Whelan 1980). But after 1910, newly independent suffrage leagues attracted thousands of women across the province to meetings, debates, plays, and lectures. The BC Political Equality League (PEL) was formed in the provincial capital of Victoria in December 1910, and by 1912 numerous affiliates had formed across the Lower Mainland and interior. By 1913, Vancouver suffragists had formed an autonomous Pioneer Political Equality League (PPEL) and Vancouver labour organizer Helena Gutteridge established the BC Women's Suffrage League, Canada's only suffrage group specifically for working-class women. As leagues flourished, the public could attend events on provincial family law, labour rights, the women's movement in China, and British suffragette militancy (Campbell 2020; Cramer 1980; Hale 1977; Howard 1992; Ihmels 2008; Strong-Boag 2018; Weppler 1971).

Print culture was critical to building the movement. Mainstream newspapers and religious, labour, socialist, and suffrage periodicals reprinted stories of local and global suffrage battles, and covered debates in the Legislative Assembly and the British House of Com- mons. Suffrage columns were penned by labour sympathizer Susie Lane Clark in the Vancouver Daily World $(V D W)$, Helena Gutteridge in the $B C$ Federationist $(B C F)$, and social gospeller Florence Hall in the Western Methodist Recorder. The province's only suffrage periodical, The Champion (1912-1914; CH), was published in Victoria by the BC PEL, and co-edited by Methodist reformer Maria Grant and British-born Dorothy Davis. Print sources were shaped by the perspectives of the most active and literate settler women in the movement, and framed by the limitations of male-dominated media outlets. But by reading media coverage and participating in local suffrage cultures, suffragists understood local activism within a larger global context even if they never left their province.

Suffragists demanded political equality through differing languages of maternalism, socialism, and liberal humanism, but most shared an underlying value system rooted in progressive modernity. Suffragists identified as members of a global movement which understood the universe as a living organism gradually advancing towards equality and justice. Enfranchisement was imagined as a contest with nations around the world engaged in a competitive race towards achieving full modernity (Dalziel 2000; NWSPC 1917). This emphasis on progress and modernity intersected with settler-colonialism and anti-immigrant xenophobia in the North American "frontier" west, and complex sentiments of British superiority in the context of global empire and international suffrage successes (Bonakdarian 2000; Devereux 2005; Forestell and Moynagh 2018; Grimshaw 2000; Henderson 2003; Lake 2019; Mawani 2009; Perry 2001; Valverde 1992). This article takes two transnational sets of ideas - the frontier myth of an egalitarian, modern, and transcontinental North American West and the framing of the Chinese women's movement as symbolic of modernity and progress_-and examines how autonomous suffrage organizations developed a consciousness of being part of a modern and global movement. Exploring these "transnational linkages" defies simplistic frameworks of sisterhood but helps historians parse how suffragists in British Columbia came to see their local movement through a global lens, and part of an unstoppable movement of modern progress (Daley and Nolan 1994; Fletcher, Levine and Mayhall 2000, xiii; Forestell and Moynagh 2011). 


\section{Suffrage Modernity}

Drawing on arguments circulating in history, science, and political theory, suffragists in British Columbia embraced the idea that the "evolution" of humanity was one of inevitable progress toward a modern and civilized world characterized by justice and equality. The movement or the "cause" was understood as the march of enlightened reason away from "barbarism" or the "dark ages," where women were subordinated to men (VDW, 2 July 1913, 7). To suffragists, advanced nation states embraced women's political participation, while those that refused to grant suffrage were backward and old-fashioned-deeply out of step with the modern world. This rhetoric borrowed from multiple philosophical traditions, including utopian socialist Charles Fourier's assertion that the status of a nation as "civilized" should be judged by the extent of women's emancipation. This idea was taken up by multiple strains of feminist thought. But the idea of progress and civilization could not have existed without interpretations of Darwin's theories of natural selection and evolutionary adaptation, which included the notion that societies evolved from simple and primitive to complex and civilized. This perspective also influenced socialists, who understood history as propelled "forward" by economic modes of production from primitive social orders, through to capitalism, and ultimately, to socialism (Angus 2009; Beecher 1990; Campbell 2000; Jones 2009; Rendall, 1994; Taylor 1993; Taylor 2003; Towns 2009).

Most suffragists mapped the idea of progressive evolution on to both race and culture, arguing that British civilization was the most advanced and that all "inferior" non-British and non-Christian cultures needed improvement. Within North American settler colonialism, the belief in progress and British superiority was instrumental in the attempt to frame British Columbia as a "white man's province" (Edmonds 2010; Harris 2003; Mawani 2009; Perry 2001; Roy 1989). The modern political body of British Columbia was built on policies that restricted Asian immigration, dispossessed Indigenous men and women, and excluded Asian and First Nations people from formal political citizenship until the late 1940s. The federal Indian Act marginalized Indigenous governance structures, where many women had held political power, and prohibited First Nations women from voting in band elections until 1951 (Barker 2006; Green 2017; Simpson 2013). The result was a suffrage movement that challenged gendered British cultural values preventing women from being treated the "same" as settler men, but otherwise left racial restrictions on the vote in place. Settler colonialism allowed suffragists to assert that Canada was a "young" country that was largely free from old prejudices_ - a "blank sheet" upon which progressive peoples could write a new history of equality and justice (Grant 1913; VDW, 22 June 1909, 11; 12 July 1909, 1; 22 May 1909, 5).

But suffragists did not have a completely linear idea of progress. The belief that British civilization was the most advanced in the world was complicated by historical evidence that women in previous generations had held power and influence (Colonist, 28 May 1895, 4, 7; CH, August 1912, 19). Suffragists struggled to explain why family law in "advanced" British societies subordinated women and children to the patriarchal authority of husbands and fathers. One of the PEL's first publications was an educational pamphlet by novelist Alice Ashworth Townley which outlined the legal power held by men over the bodies, property, and lives of women and children. These inequalities-especially laws that restricted mothers' guardianship rights - were difficult to accept for those who believed that British law was the highest achievement of civilization. Townley resolved this contradiction by arguing that while British law was generally the "best and fairest" in the world, provincial family law had not properly evolved in a modern "age of progress" (Townley 1911). Anti-suffragists had hindered British Columbia's progress, and suffragists like Townley urged the government to reject "stone age" assumptions of the past and build a legal and political framework that would usher in a modern nation. Suffragists imagined the modernization of a fundamentally British system, and it was Indigenous women themelves, not settler women, who critiqued the race-based laws that regulated the families, intimate lives, and bodies of racialized and Indigenous men, women, and children (Robertson 2012).

The growth of an international suffrage movement, 
however, somewhat complicated the easy rhetoric of the British Empire as the pinnacle of modern civilization. International news revealed that women outside of the British Empire desired political equality, and that "uncivilized" nations had given political rights to women. Sometimes the response to this information was used to racially shame anti-suffragists, who were seen as standing in the way of a modernizing society. Addressing the Men's Society at St. James' Anglican Church in Vancouver, for example, suffragist Rev. Henry Edwards argued that women in British Columbia "have not half the power held by the negro women of darkest Africa," while socialist lawyer R.B. Kerr informed a Kelowna audience that "even in China" women enjoyed political representation at the provincial assembly $(\mathrm{CH}$, October 1912, 11; VDW, 29 September 1913, 11). This information surprised some suffragists, but they were forced to address it. The Champion published a "Women of Other Lands" column which treated non-Western women as exotic others, but also incorporated awareness of women's global progress, arguing that British Columbia was falling behind the Middle East, China, and some parts of the United States. Writers drew on Orientalist tropes of victimized Middle Eastern women in "harems" awakening to their oppression. But they also highlighted how Egyptian men and women used the Qur'an to argue that gender equality was an Islamic value, and how reformers in China understood the centrality of women's equality to political transformation (August 1912, 19). Columnists followed news in Mexico, South America, Japan, and Eastern Europe, informing readers about countries unfamiliar to most women in the province. Some suffragists developed a theory of patriarchy: the belief that women had a shared experience of male domination that "meant the serfdom of woman, no matter what class she belonged to" (Bonakdarian 2000, 163; VDW, 18 August 1913, 8).

Beliefs about the progressive nature of modernity were articulated with spiritual language that understood the universe to be a living being with an inherent-and perhaps divine-force that propelled it toward greater justice and liberty. As British suffragette Barbara Wylie told a Vancouver audience, suffrage was a "fight of spiritual against physical force and spiritual always wins... The victory is bound to be on our side" (VDW, 21 January 1913, 13). This belief in the power of the universe drew together a range of suffragists: social gospel Christians, Theosophists, and socialists shared a profound belief in the "perfectibility" of both the human individual and the collective social and economic order (Allen 1971; Marks 2017; Taylor 2016; Taylor and Knott 2005). While Christian suffragists like Florence Hall understood the universe as propelled by God, others embraced non-traditional belief systems that drew on the idea of a universal movement toward justice and equality ( $\mathrm{CH}$, September 1913, 14-15). Lynne Marks notes that Theosophy was a well-known alternative faith that viewed the universe as alive and divine, and emphasized global "interconnectedness" and human equality $(2017,198-200)$. It had few official adherents but Theosophists were popular lecturers, and the Vancouver PEL even held its founding meeting in the Theosophical Hall (Province, 14 January 1911, 1).

The faith attracted a number of leading suffragists including Gutteridge, who was involved prior to leaving England, and socialist Bertha Merrill Burns, who was agnostic but influenced by Theosophical thought ( $W C$, 26 June 1903, 3; Ibid., 24 July 1903, 3). In her later years, Maria Grant left Methodism for the Unity/New Thought Church, which embraced "positive thinking" as a way to improve the self and perfect the world. Grant's philosophy influenced the tenor of the Champion, defining women's enfranchisement as "the outcome of an internal process of unfoldment and development in harmony with the law of Life. This growth experiences itself in the demand for liberty and equality." Grant believed that equality was a transformative awakening in which women realized their potential through the "annihilation of all that hinders the upward and onward winging of their way" $(\mathrm{CH}$, December 1912, 20). Those who were "asleep" were not attuned to the divine mechanisms of the universe and were unable to develop, while those who were "awake" were moving forward towards greater justice and equality.

These beliefs mark the earliest use of the feminist "wave" metaphor, evoking the power of oceanic waves and the gravitational pull of the planets. Suffrage was a 
"tide" that "could not be stayed"; it was a universal and powerful "great revolutionary wave" that would drown every person and institution in its way as it "swept" all nations into a better future (Colonist, 27 and 28 March, 1875, 4; Ibid., 15 December 1910, 21; VDW, 6 May 1911, 5; BCF, 12 December 1913, 7; CH, November 1913, 3-4). This confidence gave suffragists a rhetorical power and sense of moral certainty that inflected their speeches and writing. But this certainty was shaken by anti-suffrage politicians, such as Conservative premier Richard McBride and Attorney-General William Bowser, who helped defeat seven suffrage bills between 1903 and 1916. The fallout from 1906 legislation, which inadvertently expanded the municipal vote to a wider range of non-propertied women but was rescinded in 1908, led Victoria's Cecilia Spofford to wonder if she was wrong to believe "that the present is an age of most wonderful progression" (Cramer, 1980, 83). These failures led to the formation of independent suffrage leagues in 1910, and to increasingly vocal condemnations of provincial politicians.

\section{The Progressive West?}

The modernity imagined as animating the world took on a particular framework in British Columbia, where suffragists employed a discourse of North American Western "progressivism" to argue for settler women's equality. Settlers in the Canadian and American west were separated by a national border but shared a powerful belief that white women and families were key to "taming," "civilizing," and modernizing the frontier. The promotion of an egalitarian and economically vibrant western region resonated politically in British Columbia. Rapid economic development and white settler population growth seemed evidence of what Patricia Roy calls the "boundless optimism" embodied by Premier McBride (Dawson 2005; Kulba and Lamont 2006; Roy 2012).

The celebratory frontier partnership between hardworking white settler men and women harnessed women's political citizenship to the demographic and geographical expansion of the nation. The American West was deeply shaped by this value system and early legislative changes to white women's voting and homestead rights in the states of Wyoming and Idaho reflected the belief that white women's bodies would "settle" the West through migration, marriage, and reproduction (Lewis 2013; Lewis 2011; Mead 2004). Adele Perry argues that similar concerns existed about attracting permanent white settlement to the colony (and later province) of British Columbia (Perry 2015; Perry 2001; Perry 1995). These concerns were enmeshed with gender and racial demographics: when British Columbia entered Confederation in 1871, for example, the majority of the population was Indigenous and white women were a small minority (Barman 2007, 429). Efforts to increase permanent white settlement through racially restrictive immigration legislation and ongoing colonization led to a demographic shift. In the decade after 1901, the population of British Columbia grew by 119 percent and by 1911, almost 68 percent of the population was British in origin (Barman 2007, 429; McDonald forthcoming; Census of Canada 1911). The discourse of a land sitting "unformed" until "hard-working" men and women transformed it explained rapid British settlement as affirmation of settler partnership and hard work, and allowed reformers and suffragists to proclaim that men and women with the "broadest vision" of gender equality settled and lived in the West (Western Call, 24 March 1911, 8).

As in the American West, suffragists in British Columbia argued that that "frontier" spirit created a special kind of woman, whose work ethic set her apart from women of other regions and proved she deserved enfranchisement (Carter 2016; Carter 2006; Kulba and Lamont 2006). Vancouver suffragist Blanche Murison linked the "ambitious" modern Vancouver woman with the "tireless efforts of these indomitable women workers of the west, with their broad-gauged judgement." Such women were part of the "progress that made the story of their Last Great West such wonderful reading" (1911, 188-90), valued for their independence, hard work, and pragmatism. The Prince Rupert Journal characterized the settler woman of the "Pacific Slope" as uniquely progressive in comparison to her "slower, eastern sisters," describing her as a feminine and wise housewife who was simultaneously "strong, sweet and lovable" and full of the "western spirit" (2 May 1911, 2). 
The argument that settler women had built the modern west was reflected by the increasingly xenophobic suffrage language as the federal government brought eastern, central, and southern European immigrants to farm prairie land and work in the expanding industrial and resource sectors (Avery 1995; Avery 1979). AntiAsian racism was deeply encoded in provincial law and Japanese, Chinese, and South Asian men were disenfranchised at all three levels of government by 1906 . While non-British and non-English speaking European men were "non-preferred" immigrants, they were enfranchised after meeting residency requirements (Dua 2007; Gouto 2007; McDonald 1996; Price 2007-8; Roy 2003; Stanley 2011). Western new women made political citizenship claims by emphasizing the unfairness of withholding enfranchisement from educated, literate, and respectable women while allowing "foreign-born" men-oppositionally positioned as uneducated, illiterate, and intemperate-to vote (Avery 1995; Valverde 2008; Valverde 2000). Alice Ashworth Townley argued that it was unjust to deny the vote to settler women of British background who had "stood by" their men to build homes in "a new land" while enfranchising those she described as "fresh-coming, ignorant foreigners" (Townley 1911). Although British Columbia did not rely as heavily on European immigration as did the prairies, European men's increasing visibility sparked fears that the province was undermining its cultural superiority by allowing them permanent settlement and voting rights.

These resentments were central to Dorothy Davis's 1912 tour of the BC interior, where European immigration was more visible. The British-born Davis, who promoted unmarried women's immigration from Great Britain through the Colonial Intelligence League, claimed it was unjust to delay women's enfranchisement while giving it to "any European immigrant...however far removed his traditions and ideals of life, social and political, from Canadian standards, who has happened to be born a male" ( $K R$, 26 September 1912, 2). As capable and hard-working settlers, such women deserved the benefits of full political citizenship: "We are not content to see these foreigners being welcomed in at the front door of the house which the women of this island have borne their share of building," Davis wrote to the Colonist in 1912. "We are told to wait outside while we ask prettily through the windows for their permission to state our views" (18 September 1912). Her position was shared by Ontario-born Janet Kemp, who was elected British Columbia's PEL president in 1913. Kemp and Davis shaped the language of the 1913 suffrage petition, which promised that women's enfranchisement would increase the "British-born Electorate" and counter the "rapid influx" of European male immigrants. When Kemp met the premier, she informed him that "Anglo-Saxon" women with the vote would "safeguard the best interests of this province and its people," and would temper the votes of male "aliens" (Kemp, 1913). The argument that settler women of British descent were unfairly denied rights given to foreign men persisted until suffrage campaigns ended in 1916.

The "Pacific Slope" woman who deserved enfranchisement was not dissimilar to the new women forged in white settler societies in North America and the British Empire (Dalziel, 2000; Grimshaw, 2000; Lake, 2019; Lake, 1994). But suffragists in British Columbia kept a particularly close eye on suffrage campaigns in nearby American states. After a series of referendums delivered suffrage wins in Washington (1910), California (1911), and Oregon (1912), Susie Lane Clark remarked that most of the Pacific Coast had achieved "political equality" and wondered if "the men of British Columbia [were] going to be less just[?]...we women...think not, and look forward to very soon getting the vote" (VDW, 16 June 1913, 5). The border between British Columbia and Washington state was fluid, with suffragists, politicians, and labour organizers often travelling across it to deliver public talks or attend rallies. When the Political Equality League was formed in Victoria in 1910, for example, it was supported by a financial donation from a group of anonymous American suffragists, likely from Washington state (Colonist, 15 December 1910, 21).

If new women were forged on the Pacific coast, then so too were new men. Suffragists flattered male supporters in British Columbia and the United States as visionary westerners who were "broad-minded enough to grant women political equality” (Colonist, 6 March 
1914, 11). Seattle publisher and lawyer Adela Parker travelled regularly to Victoria and Vancouver, accompanied delegations to the legislature, and encouraged suffragists to believe that local men would follow the lead of "pioneer men" in the American West $(\mathrm{CH}$, September 1913, 9; VDW, 24 June 1913, 13). Parker gave a series of talks in the Lower Mainland, telling audiences that women's voting rights in Washington had emerged from western men's unique respect for settler women: "The men of the West have a particular regard for women and their work. This not only includes the man who has been born here, but the man who has been here long enough to become imbued with the great spirit of the West" (VDW, 2 July 1913, 7). Leagues showcased allies like Seattle city councillor Max Wardell, described as "a splendid type of the 'new man' who today is espousing woman's case by securing for her equal justice" ( $\mathrm{CH}$, December 1912, 11). The PEL's first convention featured Vancouver Mayor L.D. Taylor, under whose direction Vancouver City Council had recently given property-owning married women the municipal vote, and Seattle Democratic Senator George F. Cotterill, who had sponsored Washington state suffrage legislation in 1910 (VDW, 6 May 1911, 5).

Instead of understanding the language of frontier equality as descriptive of actual practices relating to settler women's political rights, it is best understood as a rhetorical device that served suffrage purposes and shaped claims to political citizenship. Sarah Carter (2016) shows that land and political power in the west remained in the hands of western settler men, and although women's suffrage arrived first in the prairies, the majority of provinces had followed by 1919. But discourses of western modernity gave suffragists a powerful rhetorical frame to make demands of the state. Praising equality-minded "new men," for example, was designed to both flatter and shame politicians. When the PEL pressed Vancouver Mayor Truman Smith Baxter to state his position on suffrage, his refusal led them to wonder if "the suffragists' trusting faith in the generosity of 'our big Western men' is somewhat misplaced and that perhaps the vote will not come by crying for it" ( $V D W, 2$ July 1913, 7). After multiple private members' bills failed to pass in the legislature, the PEL presented the government with a 10,000 name suffrage petition and urged McBride to live up to the masculine "Western spirit of progression," and prove he was the "strongest man" of all the Canadian premiers (Davis, 1913). After their appeals failed, Vancouver's United Suffrage Societies (USS) sent a delegation to warn McBride that the province was falling behind other world regions. After McBride insisted that women's political equality was not "in the public interest," the deputation challenged him in the language of modernity, calling him fossilized and out of place with the "progressive west" and other politicians in the "advancing" world" $(B C F$, 12 Dec 1913, 1; CH, March 1913, 5-6). Suffragists never abandoned attempts at legislative reform, but they were tired of asking for democracy and increasingly willing to demand it.

\section{Transpacific Connections: British Colum- bia, China, and Suffrage}

While British Columbia suffragists drew on transcontinental and imperial connections to inspire local activism, after 1910 they also turned their attention to the women's movement in China. British Columbia's demographic and economic ties to Asia created interest in Chinese political movements, and suffragists paid close attention to the Chinese women's movement, which fought for political citizenship and access to the professions and higher education. While most suffragists supported racial restrictions on immigration and voting, they simultaneously admired Chinese women's political leadership and by the second decade of the twentieth century, celebrated China as emblematic of political modernity.

With ongoing political upheaval in China, Chinese reformers and revolutionaries travelled to North America to win support from the diaspora and the larger public. With a significant Chinese diasporic community in British Columbia, the province was an important destination on this travel circuit (Barman 2007; Liu 2002; Stanley 2011; Stanley 2007-8). One of the earliest North American diasporic associations was established in Victoria in 1899 by Guangdong reformer Kang Youwei. The Chinese Empire Reform Association (CERA) (Baohuanghui) was transnation$\mathrm{al}$, growing to over 160 branches on multiple contin- 
ents (Chen, 2014; Leung Larson 2014; Leung Larson, 2012). Kang Youwei made numerous trips to North America and his speeches to "large public" groups in Vancouver, Victoria, and New Westminster received extensive local press coverage (Owen and Wolf, 2008). CERA advocated for modern liberal reform in China, and its call for North American governments to remove immigration and head tax restrictions and create work mobility for Chinese labourers resonated with the merchant elites who provided local leadership.

Kang Youwei and his fellow reformers imagined women's political citizenship as central to the development of a modern Chinese nation, and advocated for women's financial independence, education, and enfranchisement. His feminist principles were reflected in the commitments of his second daughter, Kang Tongbi (1881-1960), and her elder sister Kang Tongwei (who published the women's newspaper Nü Xue $B a o$ ), both of whom were active in the Chinese women's movement. Tongbi began as her father's interpreter and launched her own tour in 1903 with a two-week stay in Victoria and a series of public lectures about women in Chinese reform (Colonist, 23 May 1903, 5). To parallel the male-led CERA organized by her father, Tongbi founded the Chinese Empire Ladies Reform Association (CELRA), which had chapters in Victoria, Vancouver, New Westminster, and numerous American cities (Chen 2014; Lee 2003; Woon 2007-8). Members of CELRA were the wives and daughters of merchants in Vancouver and Victoria, and they made up the small numbers of first generation female Asian settlers.

There are two remaining CELRA posters in Canada, commemorating the Vancouver and Victoria branches (CELRA/BHH, 1903). They are visual and textual poetic celebrations of the important role women were expected to play in the political life of China and North America, and were designed to link local women to the larger Chinese women's movement and to global and modern political reform (Campbell, 2020). A photograph of the reformist Guangxu emperor is featured at the top of the poster; below him are photographs of reformers Kang Youwei and Liang Qi Chao. Positioned below the two men are images of Kang Tongbi and local CELRA members. The images are bordered by textual evocations of women's political responsibilities in an evolving nation. Images of Chinese-Canadian women were placed alongside descriptions of "great women heroes" who had sacrificed their lives to challenge authoritarianism and achieve equality. The text celebrated the martyr Joan of Arc, who had courageously "sacrificed" her life for her country and had, by the twentieth century, been adopted by many suffragists as a powerful heroine symbolizing courage and righteousness (Mayhall, 2003). She was listed alongside militant women such as Sophia Perovskaia, who had assassinated Tsar Alexander II and "wiped out the tyrant," and Feng Liao, a Chinese diplomatic envoy (Su, Ying, and Larson 2014).

Because only wealthy men could afford to bring their families to Canada under the head tax, many Chinese women living in British Columbia were of elite class status. Fragments of surviving evidence suggest that a small group of such women were involved in reform politics, including Mrs. Chan Sing Kai (Kate Chan), wife of Cantonese missionary and Methodist minister Chan Sing Kai, who founded Vancouver's first Chinese Methodist Church in 1888. After moving to Portland Oregon in 1901, Chan and her daughters became active in the local suffrage movement (OR, 12 April 1912, 16). Kate Chan's extended family in British Columbia remained committed to her vision of broader enfranchisement; her adopted daughter Eva Chan married Won Alexander Cumyow, an early leader for Chinese-Canadian political enfranchisement, and Eva and Won Alexander's son Gordon Cumyow played a central role organizing against racial restrictions on the vote in the 1940s (Nicol, 2016; Roy, 2007; Stanley, 2007-8). Although there is no record of whether CELRA members discussed suffrage at meetings or with their husbands, Vancouver CERA members were interested in the question and debated women's suffrage "with considerable animation" in a 1905 meeting. They ultimately decided that Chinese-Canadian women were not "ready" for suffrage because they had not developed "sufficient knowledge of the public questions," a position that reflected arguments made by anti-suffrage men across the province and country (Colonist, 5 December 1905, 5).

Newspapers in British Columbia covered modern 
politics in China and the travels of female reformers and journalists on the Pacific coast lecture circuit. The Colonist, for example, covered San Francisco lectures by "new woman" Sieh King, and the visits to Victoria by Kang Tongbi and Mai Zhouyi (editor of the Lingnan Women's Journal) in 1903, and of Li Sum Sing, editor of the Chinese Mail, in 1908 (Colonist, 7 November 1902, 5, 10 June 1903, 5; 5 November 1908 , 8). Press reports often ignored women's longstanding activity in Chinese reform movements and assumed that every Chinese woman was speaking for the "first time" in public. The Colonist, for example, described Kang Tongbi's lectures in typically Orientalist terms, declaring it the "first occasion on which any Chinese woman has been known to speak in public," an assessment which ignored her extensive record of global public speaking (23 May, 1903, 5). But Chinese "new women" were also intriguing to audiences because they spoke in the language of progress and modernity familiar to North American suffragists. They shared the belief that women should play a central role in modern nation building projects, and the right to economic independence and higher education (Chapman, 2016; Chapman, 2014). Chinese women reformers drew on discourses of modernization to justify women's political citizenship, and to further the political reforms they believed were necessary for a strong nation state, including democratic and responsible government. The text of one of the CELRA posters echoed the global suffrage value that women were central to modern political progress: "In the rise of the country or its fall, men and women share equal responsibility."

As with politicians and labour leaders, members of the mainstream provincial suffrage movement constructed Chinese immigration as a threat to the wages of white male breadwinners and to racialized boundaries within the province. But by the second decade of the twentieth century, suffragists were coming to understand Chinese women as an example of national modernity and global progress. This shift retained what historian Mansour Bonakdarian calls the "cultural arrogance" of British suffrage leadership, which was sustained even as the movement developed more complex understandings of women's global activism (2000, 157; Mukherjee, 2018). Suffragists in British Columbia, for example, spoke paternalistically of how "even China" was granting political rights to women. But this attitude was accompanied by increasing respect and acknowledgement that Chinese feminists did not need Western women's help to lobby for gender equality. By focusing their admiration on the activism of women in China rather than Chinese women who lived in British Columbia, however, suffragists were able to admire the Chinese women's movement - and China itself as a modern nation-while simultaneously maintaining racial boundaries between settlers and racial restrictions on political citizenship (Mawani 2009; Perry 2009).

Suffragists were attuned to women's political progress in China where, as in Canada, enfranchisement took place on the national and provincial level. Suffragists were particularly interested in Guangdong during 1911-1912, where the government removed gender, property, or education restrictions from the vote, and created a quota for women's representation in the provincial assembly. Though these rights were removed by the National Parliament during the revolution, this initial success inspired both admiration and envy as well a sense that China was in the forefront of the competitive race towards modernity (Edwards, 2008; Edwards, 2002; Edwards, 2000; Yung, 1995). "Even China is ahead of us," wrote the Champion, because it has "openly recognized the equity and advisability of calling upon her women as well as her men to take their share in the direction of national affairs, and China will therefore rise, not sink, in the scale of nations" (CH, September 1913, 9). This celebration of "advanced" nations was an important rhetorical device that took visual form in images, maps, and the iconography of public events. In 1913, the Victoria PEL entered a float rich with visual symbols of modernity, progress, victory, and justice into the Citizen's Carnival. The float was pulled by a team of horses, on which sat women dressed in militant British suffragette colours of purple, white, and green. Beside the float marched male supporters, evoking the "new men" who supported women's rights. And on top of the float stood a tableau representing the most "advanced" nations in the world. Six young women, each dressed in robes of suffrage white and victory crowns of laurel, posed in front of the door of her national "home," which was labelled with the names of the world's lead- 
ing nations where women could vote: Australia, New Zealand, Finland, Norway, Sweden, and Canton (Guangdong), China (CH, September 1913, 4). All the models were white settler women, however, and it is unlikely that organizers reached out to the ChineseCanadian women living in Victoria. The practices of the mainstream suffrage movement remained racially segregated throughout the first decades of the twentieth century.

While most suffrage organizations across the country imagined themselves as part of a global movement, transnational politics took a unique shape in Canada's western-most province. British Columbia suffragists connected with suffragists in the Western United States to argue for political equality on the supposedly progressive and egalitarian Western "frontier," and interpreted the Chinese women's movement as an example of modern and progressive national reform. Suffragists understood the development of women's rights within the global implications of modernity and were confident that white settler population growth and economic development would help British Columbia progress into a modern, egalitarian, and prosperous future. The suffrage movement in British Columbia was steeped in the cultural and ideological values of race, modern nation state formation, and settler colonialism even as it challenged others related to settler women's capacity and right to political citizenship.

\section{References}

Allen, Richard. 1971. The Social Passion: Religion and Social Reform in Canada, 1914-1928. Toronto: University of Toronto Press.

Angus, Ian. 2009. "Marx and Engels...And Darwin? The Essential Connection between Historical Materialism and Natural Selection." International Socialist Review 65 (May 2009): https://isreview.org/ issue/65/marx-and-engelsand-darwin.

Avery, Donald H. 1995. Reluctant Host: Canada's Response to Immigrants Workers, 1896-1994. Toronto: McClelland and Stewart.

1979. 'Dangerous Foreigners': European Immigrant Workers and Labour Radicalism in Canada, 1896-1932. Toronto: McClelland and Stewart.

\section{$B C$ Federationist (BCF)}

Baillargeon, Denyse. 2019. To Be Equals in our Own Country: Women and the Vote in Quebec. Vancouver: UBC Press.

Barker, Joanne. 2006. "Gender, Sovereignty, and the Discourse of Rights in Native women's Activism." Meridians: Feminism, Race, Transnationalism 7, no. 1: 127-61.

Barman, Jean. 2007. The West Beyond the West: A History of British Columbia. Toronto: University of Toronto Press.

Beecher, Jonathan. 1990. Charles Fourier: The Visionary and His World. University of California Press.

Bonakdarian, Mansour. 2000. "British Suffragists and Iranian Women, 1906-1911." In Women's Suffrage in the British Empire: Citizenship, Nation and Race, edited by Ian Christopher Fletcher, Philippa Levine, and Laura E. Nym Mayhall, 157-174. London: Routledge.

Brookfield, Tarah. 2018. Our Voices Must be Heard: 
Women and the Vote in Ontario. Vancouver: UBC Press.

Campbell, Lara. 2020. A Great Revolutionary Wave: A History of Women and the Vote in British Columbia. Vancouver: UBC Press.

2020. "Transpacific Connections: British Columbia Suffragists, China, and Encounters of Modernity." Inter-Asia Cultural Studies 20/2: 333-38

Campbell, Peter. 2000. Canadian Marxists and the Search for a Third Way. Montreal and Kingston: McGill-Queen's University Press.

Carter, Sarah. 2016. Imperial Plots: Women, Land, and the Spadework of British Colonialism on the Canadian Prairies. University of Manitoba Press.

Carter, Sarah. 2006. "British, Foreigners, Women and Land in Western Canada." Humanities Research 13 (November): 43-60.

CELRA/BHH Ladies Association. 1903. Harvard Yenching Library. https://docs.google.com/file/d/ 0By7Ajg4xYgVqMThkOTZhMmMtZWEzYS00ZT NhLTg0ZmYtM2QzMDNmNjliNTg3/edit? ddrp $=1 \& \mathrm{hl}=$ en

\section{The Champion $(\mathrm{CH})$}

Chapman, Mary. 2014. Making Noise, Making News: U.S. Suffrage Print Culture in Modernism. Oxford: Oxford University Press.

\section{Becoming Sui Sin Far: Early Fiction,} Journalism, and Travel Writing by Edith Maude Eaton. Montreal and Kingston: McGill-Queen's University Press.

Chen, Zhongping. 2014. "Kang Youwei’s Activities in Canada and the Reformist Movement among the Global Chinese Diaspora." Twentieth-Century China 39, no. 1:3-23.

Cramer, Michael H. 1980. "Public and Political: Documents of the Woman's Suffrage Campaign in
British Columbia, 1871-1917: The View from Victoria." In In Her Own Right: Selected Essays on Women's History of British Columbia, edited by Barbara Latham and Cathy Kess, 79-100. Victoria: Camosun.

Daily Colonist (Colonist)

Daley, Caroline and Melanie Nolan.1994. Suffrage and Beyond: International Feminist Perspectives. New York: NYU Press.

Dalziel, Raewyn. 2000. "An Experiment in the Social Laboratory: Suffrage, National Identity, and Mythologies of Race in New Zealand in the 1890s." In Women's Suffrage in the British Empire: Citizenship, Nation, and Race, edited by Ian Christopher Fletcher, Philippa Levine, and Laura E. Nym Mayhall, 87-102. London: Routledge.

Davis, Dorothy, 1913. Letter to R. McBride, 29 January. British Columbia Archives (BCA), GR 0441, Premier's Records, Official Correspondence Inward, v. 49, File 97, 1913.

Dawson, Michael. 2005. Selling British Columbia: Tourism and Consumer Culture, 1890-1970. Vancouver: UBC Press.

Devereux, Cecily. 2005. Growing a Race: Nellie L. McClung and the Fiction of Eugenic Feminism. Montreal and Kingston: McGill-Queen's University Press.

Dua, Enakshi. 2007. "Exclusion through Inclusion: Female Asian Migration in the Making of Canada as a White Settler Nation." Gender, Place and Culture 14, no. 4: 445-466.

Edmonds, Penelope. 2010. Urbanizing Frontiers: Indigenous Peoples and Settlers in 19th-Century Pacific Rim Cities. Vancouver: UBC Press.

Edwards, Louise. 2008. Gender, Politics, and Democracy: Women's Suffrage in China. Stanford: Stanford University Press. . 2002. "Narratives of Race and Nation in 
China: Women's Suffrage in the Early Twentieth Century." Women's Studies International Forum 25, no. 6 (November-December): 619-30.

. 2000. "Woman's Suffrage in China:

Challenging Scholarly Conventions." Pacific Historical Review 69, no. 4: 617-738.

Fletcher, Ian, Philippa Levine, and Laura E. Nym Mayhall, ed. 2000. Women's Suffrage in the British Empire: Citizenship, Nation, and Race. London: Routledge.

Forestell, Nancy and Maureen Moynagh. 2018. "Unsettling Imperial Ties: Rethinking Suffrage in the Context of Settler Colonialism in Canada." In Suffragette to Homesteader: Exploring One Woman's Memoir of Life in England and Canada, edited by Emily van der Meulen, 125-40. Halifax: Fernwood.

2019. "Historical Feminisms in Canada to 1940: Further Reflections on the So-Called First Wave." In Reading Canadian Women's and Gender History, edited by Nancy Janovicek and Carmen Nieslon, 171-202. Toronto: University of Toronto Press.

. 2005. "Mrs. Canada Goes Global." Atlantis 30, no. 1: 7-20.

Forestell, Nancy and Maureen Moynagh. 2014. Documenting First Wave Feminisms: Vol II: CanadaNational and Transnational Contexts. Toronto: University of Toronto Press.

. 2011. Documenting First Wave Feminisms: Vol.

1: Transnational Collaborations and Crosscurrents. Toronto: University of Toronto Press.

Gough, Lyn. 1988. As Wise as Serpents: Five Women and an Organization that Changed British Columbia, 1883-1939. Victoria: Swan Lake Publishing, 1988.

Goutor, David. 2007. Guarding the Gates: The Canadian Labour Movement and Immigration, 18721934. Vancouver: UBC Press.
Grant, Maria. 1913. "Letter to R. McBride, 14 February.” British Columbia Archives (BCA), GR 0441, Premier's Papers, Official Correspondence Inward, v.49, File 97

Green, Joyce, ed. 2017. Making Space for Indigenous Feminism, 2nd ed. Halifax: Fernwood.

Grimshaw, Patricia. 2000. "Settler Anxieites, Indigenous Peoples and Women's Suffrage in the Colonies of Australia, New Zealand, and Hawai i 1888-1902." Pacific Historical Review, 69, No.4 (2000): 553-572.

Grimshaw, Patricia. 2001. "Reading the Silences: Suffrage Activists and Race in Nineteenth Century Settler Societies." In Women's Rights and Human Rights: International Historical Perspectives, edited by Patricia Grimshaw, Katie Holmes, and Marilyn Lake, 31-48. London: Palgrave.

Henderson, Jennifer. 2003. Settler Feminism and Race Making in Canada. Toronto: UTP.

Hale, Linda, 1977. The British Columbia Woman Suffrage Movement, 1890-1917. M.A. thesis, University of British Columbia.

Harris, Cole. 2003. Making Native Space: Colonialism, Resistance, and Reserves in British Columbia.

Vancouver: UBC Press.

Howard, Irene. 1992. The Struggle for Social Justice in British Columbia: Helena Gutteridge, the Unknown Reformer. Vancouver: UBC Press.

Ihmels, Melanie, 2008. “The New Chewing Gum.” Okanagan History (Seventy-Second Report of the Okanagan Historical Society): 27-36.

Jones, Jeannette E. and Patrick B. Sharp, eds. 2009. Darwin in Atlantic Cultures: Evolutionary Visions of Race, Gender, and Sexuality. New York and London: Routledge.

Kealey, Linda, 1998. Enlisting Women for the Cause: Women, Labour and the Left in Canada, 1890-1920. 
Toronto: University of Toronto Press.

Kelwona Record (KR)

Kemp, Janet. 1913. "Speech to R. McBride." British Columbia Archives (BCA), GR 0441, Premier's Records, Official Correspondence Inward, v. 49, File 97, Petition, 1913.

Kulba, Tracy and Victoria Lamont, 2006. "The Periodical Press and Western Women's Suffrage Movements in Canada and the United States: A Comparative Study." Women's Studies International Forum 29, no. 3 (May-June): 265-278.

Lake, Marilyn. 2019. Progressive New World: How Settler Colonialism and Transpacific Exchange Shaped American Reform. Cambridge: Harvard University Press.

Lake, Marilyn. 1994. "Between Old World 'Barbarism' and 'Stone Age' Primitivism: The Double Difference of the White Australian Feminist.” In Australian Women:

Contemporary Feminist Thought, edited by Norma Grieve and Ailsa Burns, 80-91. Melbourne, New York: Oxford University Press.

Lee, Lily Xiao Hong, 2003. "Kang Tongbi." In Biographical Dictionary of Chinese Women: The Twentieth Century, 1912-2000, edited by Lily Xiao Hong Lee and A.D. Stefanowska, 272-274. London and New York: Routledge.

Leung Larson, Jane. 2014. "The Kang Tongbi Collection of South Windsor, Connecticut.” Paper delivered to New England Association of Asian Studies, University of Connecticut, Storrs. . 2012. "The United States as a Site for Baohuanghui Activism." Paper presented to Fifth International Conference of Institutes and Libraries in Chinese Overseas Studies, at baohuanghui.blogspot.com

Lewis, Tiffany. 2013. "Marking America’s Progress in the West: Grace Raymond Hebard's Domestication of Wyoming, Women's Rights, and Western Expansion.”
Cultural Studies/Critical Methodologies 13, no. 1: 47 57.

Lewis, T. 2011. "Winning Woman Suffrage in the Masculine West: Abigail Scott Duniway's Frontier Myth." Western Journal of Communication 75, no. 2 (March-April): 127-47.

Liu, Haiming. 2002. "The Social Origins of Early Chinese Immigrants: A Revisionist Perspective." In The Chinese in America: A History from Gold Mountain to the New Millennium, Susie Lan Cassel, edited by 2136. Walnut Creek: AltaMira Press.

Mawani, Renisa. 2009. Colonial Proximities: Crossracial Encounters and Juridical Truths in British Columbia, 1871-1921. Vancouver: UBC Press.

Mayhall, Laura E. Nym. 2003. The Militant Suffrage Movement: Citizenship and Resistance in Britain, 18601930. Oxford University Press.

McDonald, Robert A. J. Forthcoming. 'A Long Way to Paradise: British Columbia Provincial Politics, 1870 s to 1970s. Vancouver: UBC Press.

1996. Making Vancouver: Class, Status, and Social Boundaries, 1863-1913. Vancouver: UBC Press.

Marks, Lynne. 2017. Infidels and the Damn Churches: Irreligion and Religion in Settler British Columbia. Vancouver: UBC Press.

Mead, Rebecca. 2004. How the Vote Was Won: Woman Suffrage in the Western United States, 1868-1914. New York: NYU Press.

Mukherjee, Sumita. 2018. "Locating Race in Suffrage: Discourses and Encounters in Race and Empire in the British Suffrage Movement." In Suffragette to Homesteader, edited by Emily van der Meulen, 95109. Halifax: Fernwood.

Murison, Blanche. 1911. "Women of the West in Clubland: The Athenaeum Club, Vancouver BC." The BC Magazine 7, no. 3 (March): 188-190. 
National Woman Suffrage Publishing Company (NWSPC). 1917. "Votes for Women a Success." https://digital.library.cornell.edu/catalog/ss:3293932

Newton, Janice. 1995. The Feminist Challenge to the Canadian Left, 1900-1918. Montreal and Kingston: McGill-Queen's University Press.

Nicol, Janet Mary. 2016. "Canadian First: The Life of Won Alexander Cumyow (1861-1955).” BC Booklook, (28 December).

Oregonian (OR)

Owen, Patricia and Jim Wolf. 2008. Yi Fao: Speaking Through Memory: A History of New Westminster's Chinese Community 1858-1980. Victoria: Heritage House.

Perry, Adele. 2009. "Women, Racialized People, and the Making of the Liberal Order in Northern North America." In Liberalism and Hegemony: Debating the Liberal Revolution, edited by Jean-Francois Constant and Michel Ducharme, 274-279. Toronto: University of Toronto Press.

2015. Colonial Relations: The Douglas-Connolly Family and the Nineteenth-Century Imperial World. Cambridge University Press.

2001. On the Edge of Empire: Gender, Race, and the Making of British Columbia, 1849-1871. Toronto: University of Toronto Press.

1995. "Oh I'm Just Sick of the Faces of Men: Gender Imbalance, Race, Sexuality, and Sociability in Nineteenth-Century British Columbia." BC Studies 105, no. 6 (Spring-Summer): 27-43.

Price, John. 2007-8. “'Orienting' the Empire: Mackenzie King and the Aftermath of the 1907 Race Riots.” BC Studies 156 (Winter): 533-81.

Rendall, Jane. 1994. "Citizenship, Culture, and Civilization: The Languages of British Suffragists, 1866-1874." In Suffrage and Beyond, edited by Caroline Daley and Melanie Nolan, 127-150. New
York: NYU Press.

Robertson, Leslie A, with the Kwagu’ł Gixsam Clan. 2012. Standing Up with Ga'axsta'las: Jane Constance Cook and the Politics of Memory, Church, and Custom. Vancouver: UBC Press.

Roy, Patricia. 2012. Boundless Optimism: Richard McBride’s British Columbia. Vancouver: UBC Press.

2007. The Triumph of Citizenship: The Japanese and Chinese in Canada, 1941-67. Vancouver: UBC Press.

2003. The Oriental Question: Consolidating a White Man's Province, 1914-1941. Vancouver: UBC Press.

1989. A White Man's Province: British Columbia Politicians and Chinese and Japanese Immigrants, 1858-1914. Vancouver: UBC Press.

Sangster, Joan. 2018. One Hundred Years of Struggle: The History of Women and the Vote in Canada. Vancouver: UBC Press.

Simpson, Audra. 2013. Mohawk Interruptus: Political Life across the Borders of Settler States. Durham: Duke University Press.

Stanley, Timothy. 2011. Contesting White Supremacy: School Segregation, Anti-Racism, and the Making of Chinese Canadians. Vancouver: UBC Press.

2007-8. “'By the Side of Other Canadians':

The Locally Born and the Invention of Chinese Canadians.” BC Studies 156 (Winter): 109-139.

Strong-Boag, Veronica. 2018. Last Suffragist Standing: The Life and Times of Laura Marshall Jamieson. Vancouver: UBC Press.

2015. Liberal Hearts and Coronets: The Lives and Times of Ishbel Marjoribanks and John Campbell Gordon, the Aberdeen. Toronto: University of Toronto Press.

Sun, Hongmei, Hu Ying, and Jane Leung Larson, Issue 41.1\% $2020 \quad 103$ 
translation. 2014. https://baohuanghui.blogspot.com/

2014/09/the-chinese-ladies-empire-reform.html\#more.

Taylor, Barbara. 2016. "Mary Wollstonecraft and Modern Philosophy." In The Social and Political Philosophy of Mary Wollstonecraft, edited by Sandrine Bergès and Alan Coffee . Oxford University Press. . 2003. Mary Wollstonecraft and the Feminist Imagination. Cambridge University Press. 1993. Eve and the New Jerusalem: Socialism and Feminism in the Nineteenth Century: Socialism and Feminism in the Nineteenth Century. Cambridge: Harvard University Press.

Taylor, Barbara and Sarah Knott, ed. 2005. Women, Gender, and Englightenment. New York: Palgrave Macmillan.

Townley, Alice Ashworth. 1911. Points in the Laws of BC Regarding the Legal Status of Women. Vancouver: BC PEL.

Towns, Ann. 2009. "The Status of Women as a Standard of 'Civilization."' European Journal of International Relations 15, no. 4: 681-705.

Valverde, Mariana. 2000. "'Racial Poison’: Drink, Male Vice, and Degeneration in First-Wave Feminism." in Women's Suffrage in the British Empire, edited by Ian Christopher Fletcher, Laura E Nym Mayhall and Philippa Levine, 33-39. London: Routledge. . 2008. Age of Light, Soap and Water: Moral Reform in English Canada, 1885-1925. Toronto: University of Toronto Press. 1992. "When the Mother of the Race is Free': Race, Reproduction, and Sexuality in First-Wave Feminism." In Gender Conflicts: New Essays in Women's History, edited by Franca Iacovetta and Mariana Valverde, 3-26. Toronto: UTP.

Vancouver Daily Province (Province)
Vancouver Daily World (VDW)

Victoria Daily Times (VDT)

Weppler, Doreen. 1971. Early Forms of Political Identity Among White Women in British Columbia, 1880-1925. MA thesis, Simon Fraser University, Dept of Political Science, Sociology, and Anthropology.

Whelan, Gloria. 1980. "Maria Grant, 1854-1937: The Life and Times of an Early Twentieth Century Christian." In In Her Own Right: Selected Essays on Women's History of B.C. edited by Barbara Latham and Cathy Kess, 125-46. Victoria: Camosun.

Woon, Yuen-Foon. 2007-8. "Between South China and British Columbia: Life Trajectories of Chinese Women.” BC Studies 156, no. 7 (Winter/Spring): 83107.

Yung, Judy. 1995. Unbound Feet: A Social History of Chinese Women in San Francisco. Berkeley and Los Angeles: University of California Press. 